\title{
O capital mercantil no centro da América do Sul e as fronteiras do comércio na América colonial (primeira metade do século XVIII)*
}

\author{
por \\ Tiago Kramer de Oliveira \\ Universidade Federal de Santa Catarina
}

Este artigo analisa a reprodução da economia colonial no centro da América do Sul, no «termo» da Vila Real do Senhor Bom Jesus do Cuiabá. Consultando diversas tipologias documentais, investigamos como a dinâmica da economia local estava ligada a mudanças que ocorriam em contextos mais amplos, na primeira metade do século XVIII. Nosso objetivo é colocar em evidência a forma como as dinâmicas locais estavam relacionadas às "fronteiras do comércio» e a consequente expansão da exploração mercantil nos interiores da Ibero-América Colonial.

Palavras-chave: Brasil; América do Sul; comércio colonial; economia colonial; século XVIII; fronteiras.

Ao desenvolver pesquisas sobre a história das conquistas portuguesas no centro da América do Sul investigamos aspectos de uma «pequena» e ao mesmo tempo «gigantesca» espacialização da sociedade colonial ibero-americana.

Desde o princípio da conquista mais sistemática, em 1718, e durante toda a primeira metade do século, a sociedade colonial das minas do Cuiabá e do Mato Grosso, no «termo» da Vila Real do Senhor Bom Jesus do Cuiabá ${ }^{1}$, fundada

* Pesquisa desenvolvida com apoio da CAPES.

1 As duas espacialidades, minas do Cuiabá e minas do Mato Grosso, integraram o «termo» (o que equivale, em palauras atuais, ao território sob a jurisdição de um municipio) da Vila do Cuiabá até a criação da capitania de Mato Grosso, em 1748 (efetivada em 1751) e da Vila Bela da Santíssima Trindade, em 1752, já na segunda metade do século XVIII. 
em 1727, não passou de dez mil habitantes, número minúsculo em relação aos povos indígenas que habitavam os territórios que cercavam os ambientes rurais, as minas, os povoados e os arraiais portugueses ${ }^{2}$. Uma «pequena» população -formada por mineradores, sertanistas, senhores de engenho, comerciantes, fazendeiros, roceiros, artesãos, funcionários régios, brancos, negros, ameríndios e mestiços, senhores, escravos, livres pobres, homens e mulheres- que espacializava uma parcela da sociedade colonial muito distante do litoral Atlântico, nas fronteiras com os domínios hispânicos, mais especificamente fronteiriço aos territórios das missões de Moxos e Chiquitos. Pequenas espacialidades coloniais que permitiram ao império português reivindicar a incorporação aos seus domínios na América de uma «gigantesca» extensão territorial, que embora muito parcialmente conquistada, fora legitimada nas relações diplomáticas europeias como possessões portuguesas, por meio do Tratado de Madri, em $1750^{3}$.

Em uma perspectiva estrita ao aspecto econômico, os territórios que formariam, em 1748, a capitania de Mato Grosso ocupavam uma condição periférica e muito pouco significativa nos índices da economia da América colonial, o que serve como justificativa para muitos historiadores da economia percebê-los como de «pequena» importância. Por outro lado, ao problematizarmos os indícios do processo de espacialização das conquistas portuguesas nas minas do Cuiabá e do Mato Grosso, percebemos como eles expressam uma «gigantesca» urdidura de relações sociais em meio a qual pretendemos desentrelaçar algumas tramas ${ }^{4}$.

A espacialização de uma «pequenez gigantesca». Assim podemos pensar a formação de ambientes coloniais no centro da América do Sul. Seria possível que o estudo sobre uma região considerada periférica, distante dos ambientes coloniais considerados centrais, pudesse revelar aspectos do funcionamento geral da economia colonial na América? Ousamos responder afirmativamente. Portanto, embora nosso estudo centre-se em analisar a reprodução econômica no centro da América do Sul, nosso objetivo é perceber como a região articulava-se às mudanças econômicas que ocorriam na primeira metade do século XVIII, em diversas escalas ${ }^{5}$.

2 Rosa, 2003: 25.

3 Aspecto enfatizado por vários autores. Cortesão, 2001. Bastos, 1972. Davidson, 1973: 61-106. Volpato, 1987. Canavarros, 2004.

${ }^{4}$ Pretendemos, portanto, contribuir para amenizar as distâncias, na historiografia sobre o Brasil colonial, entre as abordagens que destacam a dinâmica interna da economia e aquelas que se dedicam aos estudos sobre a dinâmica externa. Para análises que enfatizam a dinâmica interna ver Cardoso, 1979; 1987. Fragoso, 1992. Fragoso e Florentino, 1998. Carrara, 2007. Para estudos que enfatizam a dinâmica externa ver Prado Jr, 1997. Novais, 1986. Arruda, 1980.

${ }^{5}$ Adotamos um posicionamento teórico-metodológico que está longe de ser novo, no entanto é ainda pouco explorado pelos historiadores econômicos. Embora nosso trabalho não esteja 
A comunicação da Vila do Cuiabá com as demais vilas do Brasil colonial foi estabelecida de forma regular por intermédio de expedições comerciais e exploratórias denominadas de «monções» ${ }^{6}$, que percorriam um roteiro essencialmente fluvial. O caminho das monções deixou de ser a única rota regular de comércio entre o litoral atlântico e as minas do Cuiabá apenas em 1737. Os Anais do Senado da Câmara da vila de Cuiabá apontam que nesse ano «chegaram os que tinham ido abrir caminho de Goiás» e trouxeram consigo «cavalarias e gado» ${ }^{7}$. Desde a abertura do caminho por terra entre Goiás e Cuiabá, a Vila Real passou a receber mercadorias - principalmente gado «vacum»e «cavalar», mas também escravos e uma diversidade de outras mercadorias- de comerciantes que estavam ligados a redes mercantis da Bahia e de Minas Gerais (figura 1).

Em um mapa de 1754, podemos visualizar uma representação desse caminho. O mapa foi confeccionado tendo como referência -além do conhecimento cartográfico acumulado ao longo dos anos- a descrição da viagem que o governador da capitania de Mato Grosso, Antonio Rolim de Moura, fez às minas do Cuiabá e Mato Grosso para tomar posse no cargo.

Percebemos que o objetivo do autor era representar principalmente os territórios que estavam no caminho entre São Paulo e os territórios da recém-fundada capitania. Portanto, o que o mapa apresenta é uma visão muito parcial sobre as ligações entre as minas do Cuiabá e Mato Grosso -e também de Goiás- com outras espacialidades. De Goiás, por exemplo, saiam caminhos que, ao norte, alcançavam o Maranhão e, ao nordeste, a Bahia. As ligações entre os territórios das minas do

comprometido a seguir um caminho teórico-metodológico pré-determinado, adotamos algumas posturas que nos aproxima de abordagens de historiadores como Carlo Ginzburg, 1989; 1990. Giovani Levi, 2000. Edward Palmer Thompson, 1987. Por outro lado não deixamos de lado a abordagem de Fernand Braudel, lembrando sua provocativa sentença de que «qualquer troca ocupa um lugar no espaço» e sua indicação de que o estudo da espacialização das atividades econômicas «é uma maneira de por em destaque o impacto da economia de mercado num dado espaço» (2005: 156). Nosso desafio neste artigo é articular àquelas abordagens que enquadraram o específico em uma perspectiva geral, as perspectivas que abordam o geral pela via do específico. Jacques Revel (1998: 20) apontou -fazendo analogia com a cartografiaque as perspectivas de construção de conhecimento histórico que se propõe a jogar com as escalas -não podem ser confundidas com os consagrados «estudos de caso» onde o contexto submete-se a um contexto pré-determinado. Um bom exemplo dessa perspectiva na história econômica é o artigo de Joseph Miller (1984) sobre a trajetória de Antonio Coelho Guerreiro. Sabedores dos limites que cercam a pretensão de ressignificar o geral a partir do particular, pretendemos- com rigor teórico metodológico e uma detida análise dos documentos - defender algumas hipóteses que podem contribuir para o entendimento da espacialização da economia colonial na Ibero-América, na primeira metade do século XVIII.

${ }^{6}$ Holanda, 1990; 1994.

7 Annaes do Sennado da Camara do Cuyabá: 1718-1830, Transcrição e Organização Yumiko Takamoto Suzuki, Cuiabá, Entrelinhas, Arquivo Público de Mato Grosso (APMT), 2007: 70. 
Figura I: Territórios entre as capitanias de S. Paulo e Mato Grosso, 1754

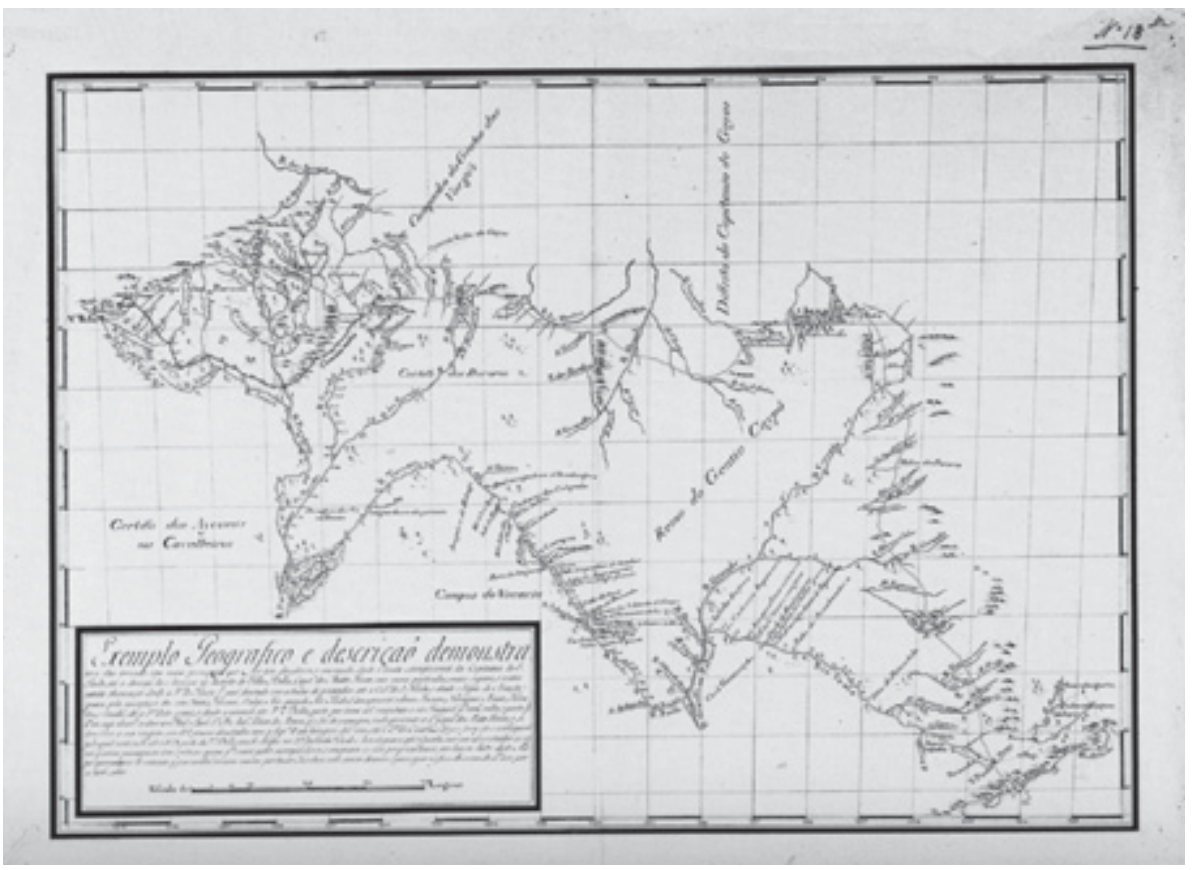

Fonte: Lucidio, 2004: 43. Neste mapa foram ressaltados (pelo autor citado) as vias de acesso.

Mato Grosso e das minas do Cuiabá com o Pará, via caminhos fluviais, e entre os territórios portugueses e espanhóis também não são representados no mapa.

Um ano antes da conclusão do caminho de Goiás, foi aberto o primeiro caminho de terra -que se tornaria o caminho velho-para as recém-descobertas minas do Mato Grosso. No detalhe do mesmo mapa, aparecem dois caminhos que ligavam a Vila de Cuiabá e a Vila Bela da Santíssima Trindade.

Tão logo as minas de Mato Grosso foram descobertas e iniciaram-se as explorações. A partir de 1734, os territórios que formariam os arraiais de Sant'Ana, Pilar e São Francisco Xavier, tornaram-se alvos dos interesses dos comerciantes, mineradores, senhores de engenho e produtores de mantimentos das minas do Cuiabá e também de Goiás.

Os anais da câmara da Vila Real registram para o mês de março de 1737: «chegou a monção», e «ao mesmo tempo saiu outra de muitas canoas e fazendas para as Minas do Mato Grosso». Já no mês de setembro: «chegaram os que tinham ido abrir os caminhos de Goiás com cavalarias e gado (...) vindo muita gente daquelas para estas de morada, com a fama do Mato Grosso», e 
Figura II: Detalhe Territórios entre as capitanias de S. Paulo e Mato Grosso, 1754

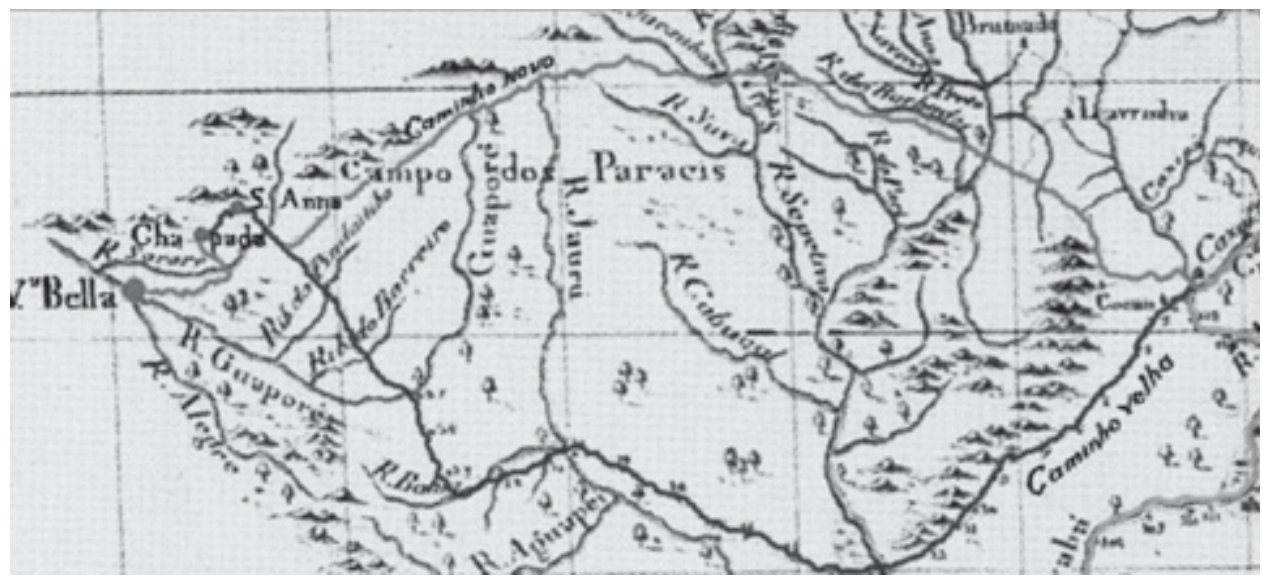

Fonte: Lucidio, 2004: 43. Neste mapa foram ressaltados (pelo autor citado) as vias de acesso.

«no mesmo mês de setembro partiu desta vila para Mato Grosso monção de setenta canoas de negócio» com mais de «1.500 pessoas capitaneados pelo (...) ouvidor João Gonçalves Pereira» ${ }^{8}$.

A comparação dos preços registrados na Vila de Cuiabá com os registrados nas minas do Mato Grosso permite-nos vislumbrar a lucratividade desse comércio.

Tabela I: Preços de mercadorias nas minas do Mato Grosso e nas minas do CuIABÁ C. 1738

\begin{tabular}{|l|c|c|}
\hline \multicolumn{1}{|c|}{ Produto } & Minas do Mato Grosso & Minas do Cuiabá \\
\hline Milho (alqueire) & 4 & 1 \\
\hline Farinha de milho & 8 & 2 \\
\hline Feijão (alqueire) & 20 & 2 \\
\hline Carne de vaca (libra) & 1 & $1 / 4$ \\
\hline Carne de porco (libra) & 1 & $1 / 4$ \\
\hline Marmelada branca (caixeta) & 8 & $1 / 2^{* *}$ \\
\hline
\end{tabular}

${ }^{8}$ Annaes do Sennado da Camara do Cuyabá: 1718-1830, APMT, 2007: 60. 
Tabela I: Preços de mercadorias nas minas do Mato Grosso e nas minas do CuiabÁ C. 1738 (continuação)

\begin{tabular}{|l|c|c|}
\hline \multicolumn{1}{|c|}{ Produto } & Minas do Mato Grosso & Minas do Cuiabá \\
\hline Açúcar (libra) & 4 & $3 / 4$ \\
\hline Galinha & 4 & 1 \\
\hline Camisa de linho & 6 & 2 \\
\hline Côvado de baeta & 4 & $1 / 2$ \\
\hline
\end{tabular}

* Não especifica que se trata de marmelada branca. Fonte.

Anais de Vila Bela da Santíssima Trindade, Instituto Histórico e Geográfico de Mato Grosso (IHGMT), Publicações Avulsas no 2: 16. Carta de João Gonçalves Pereira ao rei D. João V, 8 de setembro de 1739, Arquivo Histórico Ultramarino (AHU)-NDIHR/UFMT, mss., microfilme Rolo 02, doc. 127.

O que justificaria o milho, a farinha, a carne, as galinhas, terem preços quatro vezes mais altos em Mato Grosso do que em Cuiabá? Poderíamos seguir as imagens que atribuem às minas de Cuiabá e Mato Grosso uma produção agrícola insuficiente e precária, e afirmar que simplesmente a produção local não abastecia as minas, pois a agricultura era deixada de lado pelos mineradores ${ }^{9}$. No entanto, no mesmo documento onde os preços são discriminados, há referência de que o milho e a farinha «são produtos das roças e plantas do mesmo descoberto» ${ }^{10}$.

Mais do que registrar preços e elaborar um relato, João Gonçalves da Fonseca, com sólidos conhecimentos em cartografia, produziu mapas. André Ferrand de Almeida analisa sua Carta Hidrográfica ${ }^{11}$ e afirma tratar-se do

${ }_{9}$ Uma análise sobre essas imagens, presentes em autores como Caio Prado Júnior, Sergio Buarque de Holanda e Celso Furtado, ver Oliveira, 2011: 170-180.

${ }^{10}$ Anais de Vila Bela da Santissima Trindade, Instituto Histórico e Geográfico de Mato Grosso (IHGMT), Publicações Avulsas, nº 28: 16.

${ }^{11}$ Carta Hidrográfica em que se descreve as origens de vários e grandes Rios da América Meridional Portugueza e muito especialmente o nascimento do Rio Madeira e os rumos e sua direção, de 1750. Almeida analisa produção da Carta Hidrográfica, no contexto da viagem realizada por João Gonçalves da Fonseca, destacando «a cartografia do rio Madeira» e as diferenças entre o mapa traçado por José Gonçalves da Fonseca e o Mapa das Cortes. Almeida analisa como autoridades portuguesas não aceitaram a validade de muito do que era representado no mapa de Fonseca, pois aceitá-la significava colocar em risco a legitimidade da posse portuguesa dos territórios das minas de Cuiabá e do Mato Grosso, mesmo que segundo o autor «nenhuma outra expedição portuguesa se aproximara tanto do conhecimento daquele 
único mapa produzido por Fonseca em sua viagem ao Mato Grosso. Almeida aponta que a documentação faz referência a outro, que seria um «mapa da chapada do Mato Grosso», mas que «não se conhece o [seu] paradeiro» ${ }^{12}$. Já Mario Clemente Ferreira afirma que o mapa Configuração da Chapada das Minnas do Mato Grosso é de autoria de José Gonçalves da Fonseca e a datação por volta de 1750. Para Ferreira a atribuição da autoria e da data «justifica-se pelo facto da representação do relevo e da rede hidrográfica, e ainda da caligrafia, serem neste mapa idênticas às da Carta hydrografica» e ainda destaca «a extrema coincidência entre o que é representado na Configuração da Chapada [...] e aquilo que é descrito pelo próprio Gonçalves da Fonseca na sua Notícia da Situação de Mato Grosso e Cuyabá»» ${ }^{13}$. Vejamos o mapa ${ }^{14}$.

\section{Figura III: Configuração da Chapada das Minnas do Mato Grosso Ca. 1750}

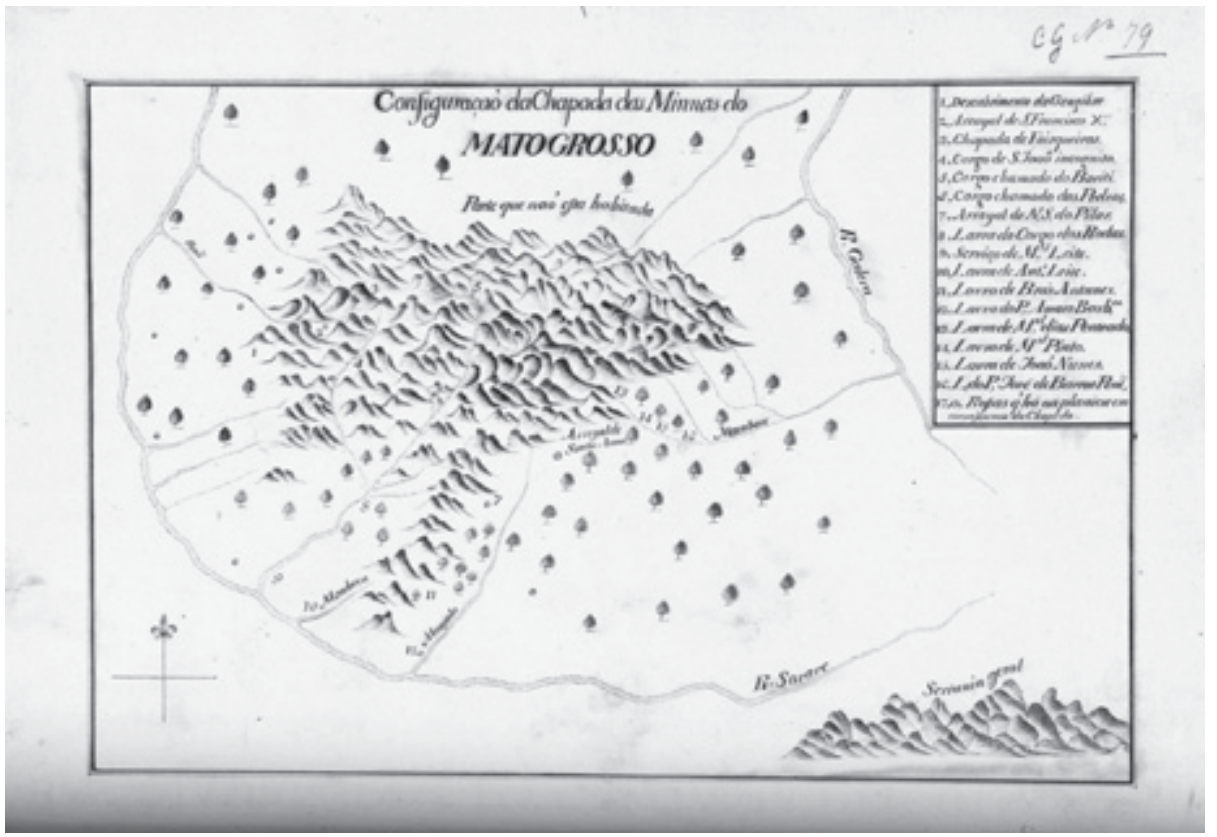

Fonte: García, 2000: 446.

espaço, e não havia de fato, qualquer outro mapa que fosse mais preciso do que aquele traçado por Fonseca». Almeida, 2009: 232-233.

12 Ibidem: 227.

${ }_{13}^{13}$ Ferreira, 2007: 6-7.

${ }^{14}$ A cópia do mapa analisado por Ferreira não é a mesma que apresentamos acima. A versão acima faz parte da coleção cartográfica da Casa da Ínsua. 
Em outros trabalhos já demonstramos a concomitância entre os descobertos nas minas do Mato Grosso e a formação de uma estrutura agrária local, diversificada e voltada para o comércio ${ }^{15}$. Na Configuração da Chapada das Minnas do Mato Grosso, além dos arraiais, rios e córregos, são indicadas muitas lavras, e cada pequeno círculo grafado na imagem indica a presença de «roças que há na planície em circunferência da Chapada». As Notícias de Fonseca são ainda mais contundentes do que o mapa, uma vez que relatam a formação de ambientes rurais, a diversidade da produção e os preços desde os primeiros anos de conquista nos arraiais do Mato Grosso ${ }^{16}$, como também o faz os Anais da Vila Bela ${ }^{17}$.

Se levarmos em conta, ainda, que em Cuiabá, em 1726, o milho valia 14 oitavas e a farinha $20^{18}$, os preços dos produtos nas Minas de Mato Grosso são bem menores do que os de Cuiabá nos primeiros anos de colonização.

Notamos, contudo, que comparando os preços entre Cuiabá e Mato Grosso por volta de 1739 , os valores das mercadorias importadas eram igualmente mais elevados. Não é, portanto, apenas na produção, mas sim nos custos e lucros do comércio, no poder de compra dos consumidores, na tributação ${ }^{19}$

${ }^{15}$ Oliveira, 2008. Ver ainda o trabalho de Gomes, 2008.

${ }^{16}$ Ao analisar $A$ Carta Hidrográfica de Fonseca, Almeida afirma que «no início da década de 1740, devido ao esgotamento de algumas lavras nas minas do Mato Grosso (...) a sobrevivência dos 'mineiros' foise tornando cada vez mais difícil». O abastecimento das regiões das minas era normalmente feito a partir dos caminhos que ligavam o Mato Grosso a Cuiabá, que, por sua vez, comunicava-se com Goiás, Rio de Janeiro e São Paulo. Mas as distâncias e as dificuldades do transporte tornavam o preço de todos os produtos, uma vez chegados ao Mato Grosso, verdadeiramente proibitivos». Almeida, 2009: 217. Como elucida Ilana Blaj, as reclamações em torno de preços, carestia, endividamentos, denotam as tensões próprias das atividades mercantis e não podem servir para construir quadros de crise e penúria em relação a reprodução da economia. Blaj, 2002: 30. A presença de representações de ambientes rurais em mapas do século XVIII, a diversidade dos ambientes representados, e suas implicações para a compreensão das conquistas portuguesas nos interiores da América, não passam despercebidas por João Carlos Garcia. Garcia, 2000: 59.

17 Anais de Vila Bela da Santíssima Trindade, IHGMT, Publicações Avulsas no 28, 2001: 16.

18 Para esta data é sempre necessário levar em conta a monção de Rodrigo César de Meneses, que desembarcara em Cuiabá com mais de 3000 mil pessoas. O relato de Gervásio Rebelo está publicado em Taunay, 1981: 103-117.

${ }^{19}$ O relato de João Gonçalves da Fonseca, escrito por volta de 1750, aponta que «um alqueire de sal, que embarrilado no Rio de Janeiro, sabe custando 2\$200; posto no Mato Grosso pelo caminho do Cuiabá, faz despesa de $28 \$ 240$, que, acomodado é por vinte e cinco oitavas de ouro: pois que em muitas ocasiões tem valido a trinta e duas (...) sempre cada carga faz a mesma despesa que a do alqueire se sal». Notícia da Situação de Mato Grosso e Cuiabá (José Gonçalves da Fonseca ca. 1750), IHGMT, Publicações Avulsas, 2001: 17. Tomando o preço da oitava por $1 \$ 500$, o preço para o comprador poderia chagar a 48 $\$: 000$, um lucro de aproximadamente $70 \%$ (sem levar em conta obviamente os demais custos e riscos). 
e nos mecanismos regulamentação política ${ }^{20}$ que encontramos a chave para a compreensão da diferença de preços entre as duas espacialidades.

Mas as diferenças entre os preços fazem com que não possamos falar de uma integração regular entre os mercados? Pelo contrário, era a diferença que estimulava os comerciantes de Cuiabá a dominar o comércio com as minas de Mato Grosso e que justificava os altos valores dos contratos de dízimos e de passagens. Era também a diferença nos preços que animava os senhores de engenho e comerciantes de São Paulo, do Rio de Janeiro, de Minas Gerais, de Cuiabá, de Mato Grosso e de Goiás, a disputarem privilégios para atender as demandas locais. Eram ainda os preços exorbitantes que estimulavam o investimento em terras e escravos para a produção agrícola em novos descobertos. Posteriormente, com a consolidação de uma estrutura fundiária e a constância demográfica, ocorria a diminuição e estabilização dos preços ${ }^{21}$.

$\mathrm{Na}$ medida em que as conquistas consolidavam possessões portuguesas mais próximas aos territórios hispânicos, os colonos passavam a ter cada vez mais contato e obter informações sobre os ambientes coloniais espanhóis do outro lado de uma fronteira ainda bastante incerta. Parte desses conhecimentos eram espacializados em documentos cartográficos.

O mapa, de 1743, assinado por João Gonçalves Pereira ${ }^{22}$, inverte o sentido leste/ oeste que estamos habituados a observar. Um documento minucioso que discrimina as distâncias, a localização das missões, a presença de «gentios» e anavegabilidade dos rios. Em que contexto este mapa emerge? ${ }^{23}$. Por enquanto, falaremos apenas de uma parte do contexto.

${ }^{20}$ João Gonçalves Pereira escreve ao rei afirmando que os preços dos gêneros em Cuiabá são os mesmos há dez anos, normatizados pela Câmara da Vila Real. Carta de João Gonçalves Pereira ao rei D. João V. 08 de setembro de 1739, Arquivo Histórico Ultramarino (AHU) NDIHR/UFMT, mss., microfilme Rolo 02, doc. 127.

${ }^{21}$ João Gonçalves da Fonseca relata que dez anos depois o milho e o feijão valiam duas oitavas o alqueire, e uma galinha $3 / 4$ de oitava, ainda assim vistos por Fonseca como amostras do «alto preço dos viveres e mais mantimentos do país». Notícia da Situação de Mato Grosso e Cuiabá (José Gonçalves da Fonseca ca. 1750), IHGMT, Publicações Avulsas, 2001: 17.

22 Presotti, 2008: 96.

${ }^{23}$ A analisar o mapa, assim Mario Clemente Ferreira o contextualiza: «Esta vontade de conhecer o lado espanhol intensifica-se a partir dos finais da década de 1730 e inícios da de 1740, quando diversos sertanistas partem de Mato Grosso em direcção às missões castelhanas de Moxos e de Chiquitos, mesmo contra as ordens da coroa portuguesa que proibia esse tipo de contactos. Embora por vezes se tenha invocado a exploração geográfica para a realização destas expedições, o verdadeiro motivo era bem menos científico. Aqueles homens, muitos deles fugidos aos seus credores, pretendiam sobretudo estabelecer comércio com as missões, uma vez que em Mato Grosso os preços eram muito elevados, sendo frequentes também as carências de muitas mercadoria. Mas isso não retira a importância aos sertanistas enquanto principal meio para a obtenção de informações acerca de novos espaços geográficos, entre os 
Figura IV: Mapa da bacia hidrográfica dos rios Guaporé e Mamoré, COM A LocalizaÇão das missões da Sociedade de Jesus, 1743

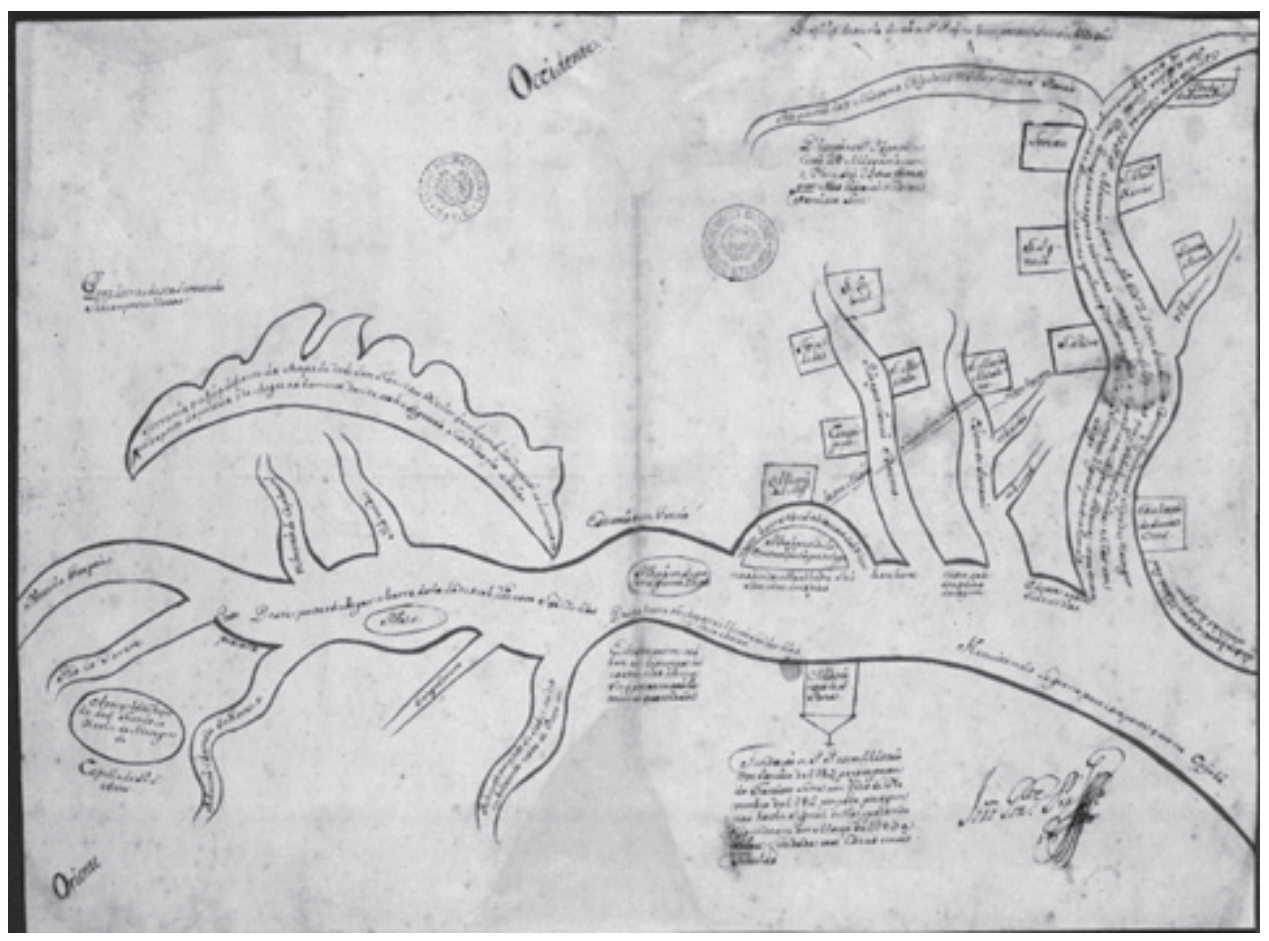

Fonte: Ferreira, 2007: 14. Presotti, 2008: 96.

Entre meados de 1730 e meados de 1740 estamos diante do período de maior intensidade das atividades econômicas reproduzidas no centro da América do Sul. Houve um contínuo crescimento demográfico: a população teria passado de 4.035 habitantes, em 1736, para 8.109, em $1745^{24}$. A produção rural cada vez mais diversificada e regionalmente especializada. Os comerciantes aproveitavam-se dos preços exorbitantes para drenar pelo caminho do comércio boa parte do ouro das novas descobertas.

quais as terras da coroa espanhola. Essa importância enquanto fontes primárias prolongou-se durante grande parte do século. Um dos exemplos que o demonstra claramente é o Mapa da bacia hidrográfica dos rios Guaporé e Mamoré, datado de 1743 e existente no Arquivo Histórico Ultramarino 13». Ferreira, 2007: 4.

${ }^{24}$ Rosa, 2003. 
As ambições dos comerciantes, mineiros, senhores de engenho e também das autoridades locais, voltavam-se cada vez mais para as perspectivas que o comércio com os territórios espanhóis poderiam oferecer ${ }^{25}$. Vimos que o ouvidor João Gonçalves Pereira, tão logo chegou a Cuiabá em 1737, exerceu função de liderança na comitiva que partiu para as minas de Mato Grosso $^{26}$. Em 1740, o ouvidor, juntamente com um grupo autodefinido como «comerciantes de Cuiabá», dirigiram uma carta a D. João V onde expuseram um plano, bastante detalhado e ambicioso, de estabelecer comércio com os territórios hispânicos. O projeto foi exposto em forma de abaixo-assinado dos «comerciantes das Minas do Cuiabá», e anexa à uma carta do ouvidor ao $\mathrm{rei}^{27}$.

No documento, os comerciantes procuraram articular seus interesses à geografia política portuguesa. $\mathrm{O}$ sistema administrativo português atribuía especial importância à dimensão territorial da conquista. Segundo o ouvidor, «fundaram os suplicantes a sua resolução no capítulo vinte e seis do regimento do vice-rei e governador geral deste Estado no qual determina v. majestade se povoem todos os domínios»».

Tanto cuidado em justificar as práticas adotadas pelos comerciantes não era um simples recurso narrativo. Era com muito receio que D. João V e seus conselheiros em assuntos do ultramar viam as relações entre os súditos das coroas ibéricas. Posicionamento político que emanava do poder central e que reverberou nas relações locais de poder desencadeando disputas e tensões ${ }^{28}$. As tensões, inerentes às disputas entre defensores e opositores da abertura de comércio com os espanhóis via centro da América do Sul, não se encerravam na câmara da vila de Cuiabá. Para termos uma noção da dimensão que tal proposta alcançou, o Conselho Ultramarino pediu pareceres

25 Jesus, 2006: 204-205.

26 Annaes do Sennado da Camara do Cuyabá: 1718-1830, APMT, 2007: 60.

${ }^{27}$ Encabeça a lista do abaixo-assinado, o nome de Luiz Rodrigues Villares, ao todo são vinte e três assinaturas, mas nem todas são rubricas dos próprios comerciantes, tendo em vista que uns assinaram «por si, outros por seus bastantes procuradores». Abaixo-assinado dos comerciantes das minas do Cuiabá ao rei D. João V. 20 de setembro de 1740, AHU, NDIHR/ UFMT, mss., microfilme Rolo 03, doc. 140. Carta do ouvidor João Gonçalves Pereira ao rei D. João V. Vila Real do Senhor Bom Jesus do Cuiabá, 20-09-1740; 20 de setembro de 1740, AHU, NDIHR/UFMT. mss., microfilme Rolo 03, doc. 140.

${ }^{28}$ O intendente e provedor de Cuiabá, Manuel Rodrigues Torres, escreveu ao rei, no mesmo ano de 1740, denunciando o ouvidor João Gonçalves Pereira de ambicionar «entregar as minas aos castelhanos» por ordem do mesmo ouvidor. O intendente e provedor ainda se queixava da «injusta prisão que sofria». Carta do intendente e provedor Manuel Rodrigues Torres ao rei D. João V. Vila Real do Senhor Bom Jesus do Cuiabá, 17 de agosto de 1740, AHU, NDIHR/ UFMT, mss., microfilme Rolo 02, doc. 136. 
dos governadores de São Paulo e do Rio de Janeiro, do procurador da Coroa e do provedor da Real Fazenda.

Voltando ao abaixo-assinado,

(...) pessoas práticas no sertão como Antonio Pinheiro de Faria, Manuel Dias [...] e outros, que saíram desta povoação no princípio do mês de julho do presente ano para [...] indagar a distância que há destas minas do Cuiabá às primeiras povoações de sua majestade católica: fundaram os suplicantes a sua resolução no capítulo vinte e seis do regimento do vice rei e governador geral desse Estado no qual determina $\mathrm{v}$. majestade se povoem todos os domínios e como para se poderem povoar é necessário explorar-se primeiro para servir no conhecimento de seus terrenos e capacidades, motivos pelos quais se dispuseram os suplicantes a concluir a dita diligência, e poderão seus habitantes ficar com contígua vizinhança aos moradores das povoações daquele monarca, e estas são subúrbios do opulentíssimo reino do Peru, sendo este abundante de riquezas, populosas vilas e cidades, como necessitado de fazendas e mais gêneros que os suplicantes conduzem a estas minas para negócio - como o mundo todo conhece-, é certo que valendo-se os suplicantes da mercê que v. majestade tem feito a seus vassalos (...) que procurem comerciar com os castelhanos pelos meios que parecerem mais convenientes (...) (grifos nossos).

Os suplicantes argumentavam que por meio do comércio os castelhanos deixariam «parte do precioso de suas riquezas e muitos gados quadrúpedes, de que abundam as pampas paraguaianas». Mais do que apenas prever os efeitos imediatos e locais, os comerciantes apontavam consequências mais amplas deste comércio: 1) «aumentarão as povoações nestes tão dilatados estados de v. majestade»; 2) «terá multiplicados os direitos da real fazenda tanto nas alfândegas dos portos marítimos», 3) «terá maior aumento o contrato dos dízimos» 4) Ampliação das lavouras para abastecer o comércio ${ }^{29}$.

Os autores do projeto propunham a construção de feitorias no rio Paraguai, relacionando-o com experiências no extremo sul da América Portuguesa, na Colônia de Sacramento ${ }^{30}$. A importância estratégica da conquista de Sacramento, desde a sua fundação, era vista pelo Conselho Ultramarino como «um modo de 'colocar prata nesse reino' e que a existência da Colônia impulsionara o desvio do metal desde as minas potosinas até o Brasil $»^{31}$.

29 Abaixo-assinado dos comerciantes das minas do Cuiabá ao rei D. João V. 20 de setembro de 1740, AHU, NDIHR/UFMT, mss., microfilme Rolo 03, doc. 140.

${ }^{30}$ Não devemos perder de vista que, mesmo consentido extraoficialmente pelo rei, o comércio via Sacramento assim como qualquer prática de comercio entre as fronteiras portuguesas e espanholas era ilegal.

${ }^{31}$ Ameghino e Birocco, 1998: 34. 
Havia o interesse em desenvolver o comércio via centro da América do Sul com os castelhanos, e existia um conjunto de enunciados que o justificava. A diferença espacial, contudo, não poderia ser ignorada. Os comerciantes de Cuiabá e o ouvidor João Gonçalves Pereira queriam provar que era mais conveniente realizar o comércio com os espanhóis pelo centro do que pelo extremo sul do subcontinente americano ${ }^{32}$,

(...) caso tenha efeito este projeto é ímpar que arraia com vizinhos tão inconstantes como a experiência tem mostrado com os sucessos de nova colônia de Sacramento (...). (...) entrada aos navios que vierem das Índias Ocidentais, rio da Prata, Buenos Aires com prata, couro, e outras fazendas que não sejam da Europa e Índia Oriental, que possam comerciar livremente, levando em troca escravos e outros gentios deste Estado; e que quando se não abrisse o dito comércio por parte dos castelhanos (...) os ditos governadores todo o cuidado e diligência para se abrir por via dos portugueses pelos meios convenientes, que pudesse ser, e que lhe reputaria por particular serviço; e na conformidade dos ditos regimentos se tem abrir o comércio com os castelhanos pela nova Colônia de Sacramento, Rio Grande de São Pedro e por esta capitania de São Paulo, sendo o governador dela Antonio da Silva Caldeira Pimentel.

Foi com muita cautela que a Coroa avaliou o desenvolvimento de relações comerciais com os espanhóis via centro da América do Sul. Na resposta de D. João V, enviada em carta em 1746 à Vila Real, foram citados os pareceres do governador de São Paulo, do governador do Rio de Janeiro, do procurador da Fazenda Real e do procurador da Coroa. Apesar dos pareceres diferenciados nenhum deles apoiou a proposta dos comerciantes, prevalecendo uma política de defesa com a proposta da construção de fortalezas e não de feitorias ${ }^{33}$. A consulta do Conselho Ultramarino acatada por D. João V, não apenas fazia referência às feitorias,

as bandeirinhas sertanejas e abertura de picadas ou caminhos novos serviam de alguma utilidade particular, mas de prejuízo e ruína do público, porque muitos morriam nas mãos dos bárbaros, e se fazia notório aos castelhanos a vizinhança de nossas terras, ou do nosso ouro e diamantes, o que se fazia muito perigoso, tendo aquela nação mais poder, e sendo mais numerosa que a nossa; e que assim parecia se devia repetir a ordem que proíba abrir caminhos novos principalmente para a parte que confina com os castelhanos e o comerciar com estes.

32 A proposta dos comerciantes coincidia com um período de «inflexão da estratégia lusitana» no qual Portugal abriu mão das áreas agrícola ao entorno da Colônia que, «a partir de então, assumia a constituição de um porto comercial sem um entorno agrícola e uma possível moeda de troca por territórios de Espanha». Prado, 2002: 53.

${ }^{33}$ Consulta do Conselho Ultramarino ao rei D. João V. 26 de abril de 1746, AHU, NDIHR/ UFMT, mss., microfilme Rolo 03, doc. 196. 
No mesmo documento o conselho sugere que ministros envolvidos no comércio com os territórios espanhóis deveriam perder seus cargos e os comerciantes «que por si, ou por outrem, fizerem aquelas negociações» teriam «confiscados os bens» ${ }^{34}$. Via-se frustrada a intenção dos colonos e autoridades administrativas em introduzir - de forma pactuada com o poder real- suas mercadorias, via centro da América do Sul, ao «opulentíssimo reino do Peru».

Quando questionamos o contexto no qual emergiu o mapa de 1743, respondemos que falaríamos apenas de uma parte do contexto. Agora falaremos de outra, do outro lado da fronteira.

Havia uma longa história de relações comerciais na bacia do rio da Prata, entre os súditos portugueses e espanhóis. Desde os tempos da União Ibérica, bem antes da fundação de Sacramento, os portugueses tinham uma importante presença na praça comercial de Buenos Aires ${ }^{35}$. Em seu conhecido estudo sobre a província de Córdoba, Assadourian aponta que em 1590, o comércio de sebo para o Brasil e de gado a pé para Potosí bifurcava as exportações da produção ganadeira da região ${ }^{36}$.

O maior volume do comércio de exportação via Buenos Aires era realizado por meio de práticas de contrabando. Segundo Moutoukias «entre 1590 y 1640 , el tráfico intercolonial que unía el Río de la Plata con las costas brasileñas y las colonias portuguesas da Africa occidental representó la mayor parte de aquella actividad portuaria». Depois de uma decadência nesta primeira fase, os navios holandeses permitiram a recuperação do volume de comércio a partir da década de 1640. Entre 1675 e 1680 o ritmo diminuiria, até a fundação da Colônia de Sacramento, o que para Moutoukias «creó um nuevo aje de actividad comercial clandestina» ${ }^{37}$.

A Coroa espanhola não apenas tinha conhecimento do comércio ilegal realizado em Buenos Aires no século XVII como o incentivava e procurava controlá-lo, aliando-se às elites locais e aos interesses dos funcionários régios nomeados para a região. No período de 1590 a 1640 , entre 80 e $85 \%$ das exportações eram de metais preciosos e teriam sido importados mais de 25.000 escravos $^{38}$. Como a conivência com o contrabando poderia ser interessante para a administração?

O domínio territorial da região era fundamental para os interesses da Coroa. O que não significa que os interesses por territórios suplantavam os interesses

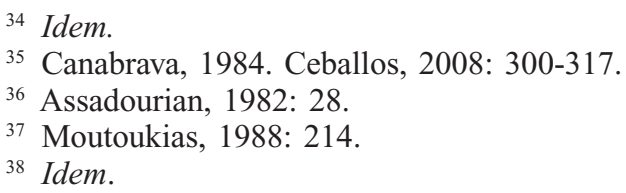


econômicos. Ao contrário, como afirma Moutoukias, manter a região de Buenos Aires povoada- com uma elite de comerciantes formada por moradores locais e por autoridades metropolitanas, com atividades produtivas agrárias articuladas ao comércio, com um sistema administrativo que respondesse diretamente ao rei e com uma guarnição que chegou a somar entre 900 e 1.000 homens no final do século XVII- era fundamental para defender as riquezas do Alto Peru. Era justamente a existência de riquezas que permitia à Coroa e aos particulares utilizar o contrabando em favor dos seus interesses políticos e geopolíticos.

Com a fundação da Colônia de Sacramento, contudo, não eram mais comerciantes particulares portugueses envolvidos na trama do sistema administrativo que faziam comércio clandestino em territórios espanhóis. O que ocorrera foi a edificação de um aparato comercial e militar do império português na costa oriental do rio da Prata em frente a Buenos Aires. Lugar que passou e ser o principal entreposto comercial do Atlântico para a bacia do rio da Prata. Entretanto, o comércio favoreceu as elites de Buenos Aires que passaram a receber mercadorias com menores preços e maior volume para comercializá-las com o interior da América espanhola. Com os lucros poderiam investir em terras para expansão das atividades pastoris, principalmente na criação de gado $^{39}$. Como aponta Moutoukias, «al igual que en otras regiones de América española, los grupos dominantes formaban un conjunto polivalente que se apoyaba simultáneamente en la tierra, el comercio y la administración» ${ }^{40}$.

A intensificação do comércio extraoficial português na América espanhola ocorreria justamente em meio a um período identificado, por muitos historiadores, como de crise das relações da Espanha com seus territórios coloniais. Crise que ficaria ainda mais aguda no entrar do século XVIII com a Guerra da Sucessão Espanhola. Entre 1708 e 1722, por exemplo, nenhuma feira foi

39 Assim Fabricio Prado resume a posição de Sacramento na primeira metade do século XVIII: «Sacramento era responsável pelos contatos diretos com o mercado atlântico e pela introdução de mercadorias europeias e brasileiras a baixos preços. Além disso, o porto de Sacramento era melhor para abrigar embarcações maiores, possuía diversas ilhas que facilitavam os descarregamentos de mercadorias e era o principal porto para reparos de barcos no rio da Prata na primeira metade do século XVIII. Entretanto, os luso-brasileiros, a partir de 1735-37, viram-se privados da exploração dos recursos da campanha pela ação bélica do patriciado portenho. Evocando cláusulas diplomáticas do segundo tratado de Utrecht, a elite de Buenos Aires buscou controlar os recursos pecuários da campanha oriental, nomeadamente, buscou evitar que os habitantes de Sacramento explorassem o gado (vacum e cavalar), ou se internalizassem na campanha. Entretanto, o predomínio da elite portenha sobre as redes comerciais com regiões interioranas a tornava dependente do comércio direto com a Colônia». Prado, 2003: 82.

${ }^{40}$ Moutoukias, 1988: 214. 
realizada em Portobelo, no atual Panamá, tradicional local de comércio de produtos trazidos pelos espanhóis para suas colônias. A partir de 1702, o «asiento»-concessão de direitos sobre o fornecimento de escravos para a América hispânica- foi concedido a uma companhia francesa, que não apenas controlou o comércio de escravos, mas também o contrabando de outras mercadorias, participando, inclusive, da «carrera» oficial, já que fornecia os navios para protegê-la. Posteriormente, em 1713, uma companhia inglesa obteve o «asiento» e também o direito a um comércio que deveria ser bastante limitado, mas ultrapassava em muito as fronteiras impostas pelos tratados ${ }^{41}$. Os ingleses construíram armazéns para estocar mercadorias e edificações para acondicionar os escravos em locais como Portobelo e Buenos Aires ${ }^{42}$. Embora sem o «asiento», os franceses receberam «permisos» para o comércio pelo Mar del Sur, passando da costa atlântica à pacífica pelo cabo de Hornos.

Em meio à crise política, ocorreu uma acelerada dinamização das atividades econômicas nos territórios espanhóis na América, que pôde ser assim resumida,

Os comerciantes estrangeiros apareceram em pequenas cidades coloniais, onde não haviam sido vistos por quase um século. A produção de prata na Nova Espanha voltou a crescer e logo seria reestabelecida no Peru. As exportações de cacau na Venezuela para a Nova Espanha, para Espanha e para Curaçao alcançaram novos picos. Cresceu o comércio entre o México e o Peru, o México e as Filipinas, e o Peru e Buenos Aires. Havana estabeleceu rotas para muitos dos portos do mar dos Caraíbas. Novas regiões aumentaram de importância. Cuba, Puerto Rico e Santo Domingo, agora mais supridas de escravos, tornaram-se ilhas agrícolas, que negociavam açúcar com estrangeiros e com a metrópole. O contrabando foi o principal comércio em quase toda a parte, embora também o comércio ilegal com a Espanha estivesse atingido novos picos ${ }^{43}$.

Apesar de conceder para franceses e para ingleses importantes setores do comércio colonial, a Coroa espanhola e os comerciantes de Cádiz não deixaram de fazer valer seus interesses na América espanhola. Interesses que acabaram por favorecer o comércio com o Alto Peru via Buenos Aires, com a concessão de numerosas licenças, principalmente a partir da década de $1730^{44}$.

Havia ainda um comércio de contrabando do México para o Peru -entre Acapulco, na costa pacífica, e as cidades portuárias como El Callao, Paita y Guayaquil.

\footnotetext{
41 Donoso Anes, 2007: 105-144.

${ }^{42}$ Macleod, 1997, vol. 1: 385-388.

43 Ibidem: 388.

${ }^{44}$ Parrón Salas, 1997: 459.
} 
Com tal comércio, o Peru era abastecido tanto de mercadorias das frotas espanholas, quanto do «navío de permiso» inglês ${ }^{45}$.

Nesse contexto, o lugar do Alto Peru e do Peru na economia da América era muito diferente de um século atrás, no período em que a prata do Alto Peru desempenhava um papel maior tanto nas exportações de prata para a Europa, a partir, principalmente, dos portos do Peru, quanto na dinâmica das trocas inter-regionais no interior do que Assadourian definiu como «espaço peruano» ${ }^{46}$.

Cerca de trinta anos antes do envio para D. João V do plano elaborado pelos comerciantes de Cuiabá, uma proposta, com enunciados parecidos mas com uma dimensão incomparavelmente mais ampla, foi elaborada pelo vice-rei da Nova Espanha, o duque de Linares. Em comunhão com os interesses dos comerciantes resididos no México, Linares propôs, em 1711, que o comércio entre Peru e Espanha deveria ser feito através dos portos mexicanos de Acapulco, no Pacífico, e Veracruz, no Atlântico, eliminando a rota dominada pelos franceses e abandonando a expectativa de reativar os «galeones» de Portobelo. A proposta colocava o México não apenas como privilegiado abastecedor do mercado peruano, mas como «epicentro do comércio hispano-americano», articulando as rotas com a Europa e com o oriente via Filipinas ${ }^{47}$.

Por meio do estudo de Mariano Bonialian, sabemos que a proposta foi não apenas rejeitada pela Coroa espanhola, como as práticas mercantis que já ocorriam foram denunciadas. A carta do Consejo de Indias que condenou o plano de Linares é finalizada «exhortando por el cumplimiento de las órdenes reales y medidas punitivas que alientan la restricción del tráfico transpacífico y la total prohibición del comercio por la Mar del Sur» ${ }^{48}$. No entanto, Bonialian aponta que a proposta visava a oficialização e o fortalecimento de vias de comércio já existentes entre México e Peru, de onde além de prata vinham outras mercadorias como o vinho e o cacau que embarcavam junto com a produção da Nova Espanha para os mercados europeus. A partir de 1739, contudo, com a guerra entre a Espanha e a Inglaterra e a paulatina abertura do comércio direto com a Espanha com vários portos coloniais o comércio entre México e Peru perdeu a importância ${ }^{49}$.

Toda a complexa relação de abastecimento interno do Alto Peru era muito diferente antes da primeira metade do século XVIII, quando ainda funcionava

${ }^{45}$ Bonialian, 2011: 8.

${ }^{46}$ Espaço que compreenderia o território dos atuais: Equador, Peru, Chile, Argentina e Paraguai. Assadourian, 1982: 110-111.

47 Bonialian, 2011: 12-15.

48 Ibidem: 15.

49 Ibidem: 15, 26. 
o regime de frotas que traziam mercadorias de Cádiz para a América Espanhola. Embora houvesse o contrabando, a coroa não permitia o comércio entre Nova Espanha e os territórios peruanos, assim como era proibido o comércio via bacia do rio da Prata. De um modo geral, o comércio interior era dominado pelas elites criollas e o comércio com o atlântico pelos comerciantes peninsulares. Com a crise das frotas de «los Galeones», o Estado espanhol utiliza-se do mecanismo «de la internación y las gentes de España penetran en las blindadas economías 'interiores' ${ }^{50}$. Segundo Parrón Salas, a chave básica para entender as relações entre o Peru e Cádiz entre 1740 e 1778 é a «internación». O termo designa o acesso, por comerciantes peninsulares, a mercados interiores com a edificação de espaços com jurisdição própria de onde poderiam ser vendidas mercadorias europeias para os maiores mercados da América espanhola do século XVIII que ficavam no interior do continente ${ }^{51}$.

Do outro lado da fronteira, os comerciantes de Cuiabá e o ouvidor João Gonçalves Pereira tinham uma boa dimensão da dinâmica do abastecimento via costa pacífica na década de 1740 ,

por ficar sendo aos castelhanos o trato que a eles oferece por estes arraiais com mais comodidade da distância, do que pela Colônia (Sacramento) com os portugueses; e pela contra costa do mar [...] com os franceses, holandeses e ingleses, e havendo guerras [...] os socorros dos (castelhanos) será o dito comércio ${ }^{52}$. (parênteses nossos)

Uma percepção relativamente clara da dinâmica econômica que envolvia o comércio Atlântico e Pacífico por parte dos comerciantes é reveladora de como em uma região na qual estes oceanos eram quase equidistantes pensavam-se e desenvolviam-se atividades econômicas tendo como parâmetros a dinâmica do Império Português, do qual esse território fazia parte, como colônia, no limite de sua fronteira, e o Império Hispânico com o qual rivalizavam territórios litigiosos e estabeleciam direta ou indiretamente uma série de contatos.

Como observa David Davidson, a decisão da Coroa portuguesa em não permitir o comércio com os territórios espanhóis justifica-se em boa medida pela geopolítica das duas Coroas ibéricas em relação ao centro da América do Sul. Ambas decidiram por políticas defensivas. A Espanha pelo fortalecimento das missões jesuíticas que cercavam as entradas para o Alto Peru, e

${ }^{50}$ Parrón Salas, 1996; 1997: 457.

${ }^{51}$ Idem.

52 Carta do ouvidor João Gonçalves Pereira ao rei D. João V, 20 de setembro de 1740, AHU, NDIHR/UFMT, mss., microfilme Rolo 03, doc. 140. 
Portugal pela manutenção dos territórios fronteiriços que colocavam o limite das possessões portuguesas bem distantes de suas maiores reservas minerais ${ }^{53}$.

Contudo, pela resposta que o sistema administrativo português ofereceu à iniciativa dos comerciantes, podemos perceber não apenas parte da dinâmica do comércio de fronteira diante dos interesses particulares dos colonos e geopolíticos da Coroa, mas também podemos ter uma percepção sobre as «fronteiras do comércio» e sua relação com o sistema administrativo português.

No mesmo ano da resposta que frustrou o interesse dos comerciantes, 1746, foi elaborada uma representação cartográfica em uma escala muito maior do que a do mapa de João Gonçalves Pereira, que representava, com desproporcional destaque, um caminho entre Cuiabá e San Rafael.

O caminho obviamente preexistia em relação ao mapa e mostra uma ligação que muito provavelmente era bem conhecida dos comerciantes que fizeram a proposta ao rei, pois a feitoria deveria ficar justamente em meio a

Figura V: Territórios do Norte e do Centro do Brasil, 1746

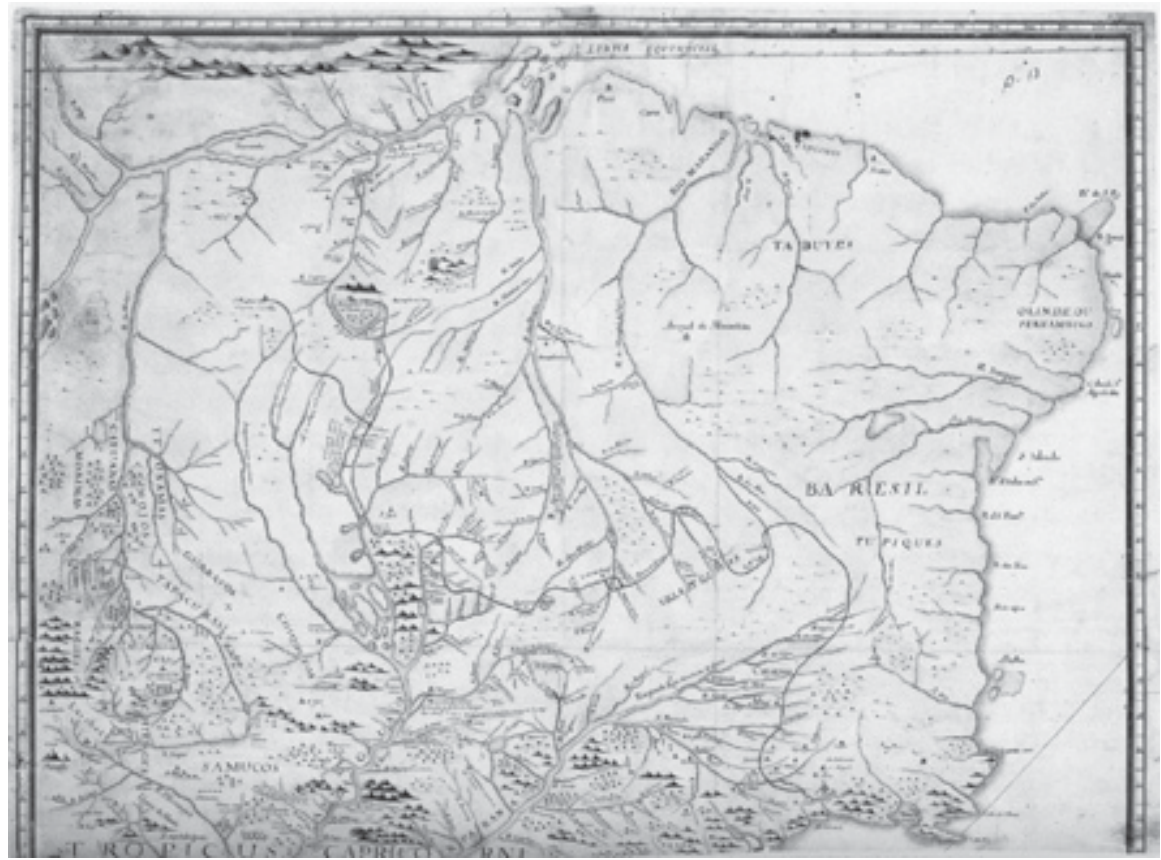

Fonte: Garcia, 2000: 326.

53 Davidson, 1973: 91. 
este caminho. Havia várias missões no itinerário e não é por acaso que San Rafael é representada. Por um lado a missão era «o centro nervoso da rede de vigilância jesuítica» ${ }^{54}$ na fronteira, por outro era acesso privilegiado aos caminhos que levavam aos grandes mercados do Alto Peru.

Figura VI: Detalhe Territórios do Norte e do Centro do Brasil, 1746

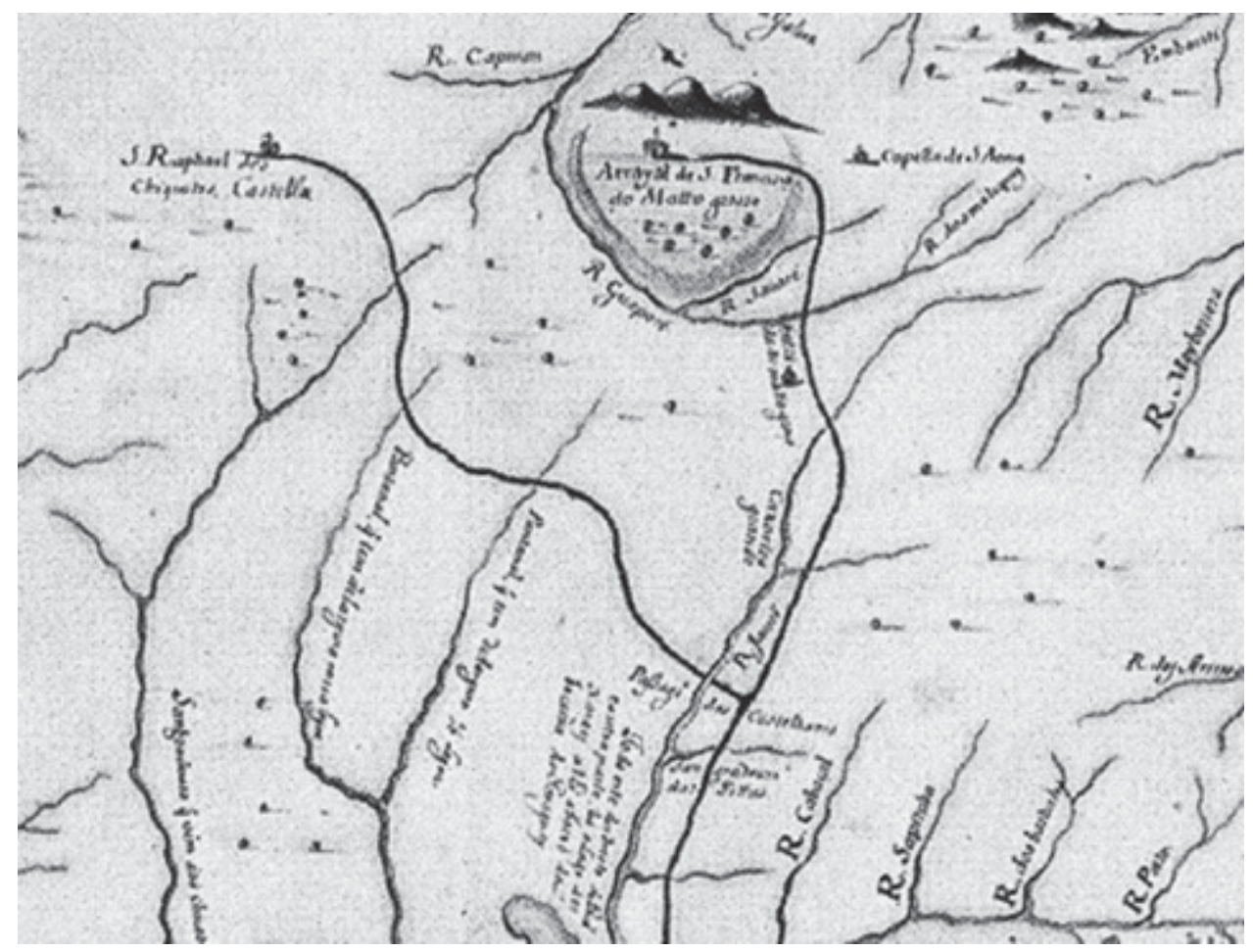

Fonte: Garcia, 2000: 326.

E, de fato, não apenas a representação do caminho, mas também o comércio na fronteira entre as espacialidades passaria a ser planejado em outra escala. Além da espacialização de ambientes coloniais fixos, o acúmulo de conhecimentos que o sistema administrativo português reuniu com as correspondências, notícias, petições, cartas, denúncias, serviu aos seus interesses

${ }^{54}$ Ibidem: 86. 
geopolíticos. Por meio também das malhas do sistema administrativo ${ }^{55}$, o monarca e os grupos mercantis hegemônicos obtiveram informações sobre as potencialidades do comércio, lugares estratégicos de abastecimento, locais ideais para construções de fortes para a defesa, e também para a prática de atividades mercantis com o lado espanhol.

Já sob a égide do Marquês de Pombal, a Companhia de Comércio do Grão-Pará e Maranhão, criada em 1755, passaria a monopolizar as atividades ilegais de comércio. Os comerciantes e produtores de Cuiabá e Mato Grosso deveriam submeter-se às regras da Companhia sendo muito mais vigiadas e duramente punidas as práticas particulares de contrabando ${ }^{56}$.

Os comerciantes estavam dispostos a investir «grossos cabedais» em atividades de comércio com o lado espanhol. Investiram sem garantia de retorno meia arroba de ouro em apenas uma das expedições que fizeram ${ }^{57}$. Contudo, eram muitos os interesses que impediam o consentimento e apoio real ao projeto dos comerciantes.

Existia desde antes mesmo da fundação de Sacramento uma relação íntima entre grupos mercantis portugueses com o comércio na Bacia do Prata. E a partir de 1680 as relações de comércio via Sacramento envolviam uma elite mercantil cada vez mais fortalecida e autoridades muito influentes com importantes cargos na administração colonial e no Conselho Ultramarino ${ }^{58}$, cujos interesses não poderiam ser ignorados por D. João V.

Notamos na proposta o cuidado de João Gonçalves Pereira em deixar claro que não passariam para o lado português mercadorias europeias vindas do comércio via oceano Pacífico, pois o ouvidor tinha clareza dos limites para as relações «coloniais» inerentes às práticas mercantis.

Havia, portanto, fronteiras que impediam o livre investimento e reinvestimento do capital mercantil na ampliação das atividades comerciais. O comércio abria oportunidades para a expansão de outras atividades econômicas, como a mineração, a agricultura e a pecuária, mas os negócios mais lucrativos, obtidos via arrematação de contratos, monopólios de exploração, consentimento real para o comércio legal e ilegal, envolviam relações de poder típicas da Época Moderna e, em relação aos territórios coloniais, expressivas de sua

55 Sobre a noção de «sistema administrativo», ver Bethencourt, 2007: 200.

${ }^{56}$ Em 1755 foi fundada a Companhia de Comércio do Grão-Pará e Maranhão que monopolizaria o comércio legal entre Portugal e o Estado do Grão-Pará e Maranhão e que também desenvolveria o comércio ilegal, embora oficial, com os territórios espanhóis via Mato Grosso. Rodrigues, 2008. Sobre as relações de fronteira entre os territórios da capitania de Mato Grosso e da América espanhola ver Chaves, 2009.

${ }^{57}$ Canavarros, 2004.

58 Prado, 2002: 49. 
«condição colonial». Não existe alternativa que não a diversificação de investimentos e o direcionamento para outras atividades, também vinculadas ao capital mercantil e que embora menos lucrativas são também mais seguras e acessíveis àqueles que dispõem de capitais para comprar escravos e comprar e/ou conquistar terras.

Em nossas pesquisas sobre a reprodução de atividades econômicas no contexto da expansão das práticas sertanistas, na primeira metade do século XVIII, temos analisado uma farta documentação. Documentos que possibilitam que a intepretação que apresentamos encontre mais solidez. Analisamos cerca de quatrocentos requerimentos e concessões de terras por meio de cartas de sesmarias, no âmbito da capitania de São Paulo no período entre 1720 e 1750. É evidente nessas concessões que, de uma forma geral, a ocupação das terras estava intimamente articulada à estruturação de elites mercantis das vilas e cidades coloniais ${ }^{59}$. Localizamos 46 requerimentos de sesmarias no caminho entre Taubaté e Parati (importante caminho de comunicação entre São Paulo e Rio de Janeiro). A grande maioria dos requerentes, $82 \%$, moravam no termo da vila onde as terras estavam localizadas. As cartas, em conjunto com outros documentos ${ }^{60}$, permitem afirmar que na região havia uma elite em condições de explorar terras em extensões que só podem ser justificadas pela utilização do trabalho escravo. O principal objetivo dos requerentes era a lucrativa atividade de produção de «mantimentos» nos caminhos do comércio ${ }^{61}$.

Os grupos mercantis da cidade de São Paulo também pareciam dispostos em investir na expansão das atividades rurais. De um total de 60 requerimentos de sesmarias para os «campos gerais de Curitiba» e em seus caminhos, entre 1720 e 1740 , apenas $21,6 \%$ eram de requerentes que informavam viver em regiões próximas das terras requeridas, $41,6 \%$ não informaram o local de moradia. Entre os que informaram $62,8 \%$ diziam ser moradores de vilas distantes das terras requeridas, como São Paulo (20\%), Santos $(14,2 \%)$ e Paranaguá $(14,2 \%)$. Pelo perfil dos requerimentos podemos afirmar que havia um significativo investimento na criação de gado nos campos de Curitiba na

59 Sobre a emergência de elites mercantis locais ou sobre a mercantilização das atividades econômicas internas no Brasil colonial, entre o final do século XVII e princípio do XVIII, ver os trabalhos de Flory, 1978. Mello, 1995: 23-187. Blaj, 2002. Sampaio, 2001. Borrego, 2006. Alves, 1998.

${ }^{60}$ Carta do governador e capitão general da capitania de São Paulo, Rodrigo César de Meneses, ao rei D. João V, 23 de abril de1725, AHU, ACL- CU- 023, Cx. 1, doc. 51. Requerimento de Sesmarias de Domingos Antunes Fialho Domingos, Rodrigues de Carvalho, Antônio da Silva, Antônio Ribeiro e outros, 02 de agosto de 1725. Requerimentos de sesmarias da Capitania de São Paulo. Arquivo Público do Estado de São Paulo (APESP), doc. 80-02-19.

${ }^{61}$ Requerimentos de sesmarias da Capitania de São Paulo, APESP. 
primeira metade do século XVIII. Ao contrário da região entre Taubaté e Rio de Janeiro, a grande maioria dos requerentes já havia conquistado as terras que pediam por sesmarias e iniciado a criação de extensos plantéis de «gado vacum» e também, embora em menor medida, a criação «gado cavalar» ${ }^{62}$. Não há dúvida que parte dos lucros oriundos de atividades mercantis desenvolvidas em localidades como a cidade de São Paulo e vila Santos foi investida na criação e no comércio de gado ${ }^{63}$.

Nas 36 cartas de sesmarias concedidas entre 1726 e 1727 no termo da Vila do Cuiabá pudemos perceber a articulação entre a espacialização de atividades rurais e a reprodução do capital mercantil, inclusive por meio de redes de interesses -e de parentesco- que uniam membros da elite local com a elite residida na cidade de São Paulo ${ }^{64}$. É possível perceber ainda como a espacialização da ruralidade -roças, engenhos, fazendas currais- estava articulada ao comércio de abastecimento local (tanto da população residente quanto dos «viandantes» e à expansão das atividades econômicas sertanistas como o aprisionamento de índios e a exploração de ouro ${ }^{65}$.

Acreditamos que, na primeira metade do século XVIII, o amplo investimento em atividades agrárias voltadas para o mercado colonial justifica-se mais pelas «fronteiras do comércio»-que ao mesmo tempo limitam o acesso a setores mercantis mais lucrativos e abrem caminho para a mercantilização da produção agropastoril -do que pelo desejo senhorial de possuir terras e escravos.

E o que dizer das rendas deslocadas para fins considerados aristocráticos? A compra de cargos, de títulos, a prestação de serviços ao «bem comum» como construção de casas de misericórdia, abertura de caminhos, contribuições voluntárias, que depois são utilizadas para justificar pedidos de mercês- eram formas comuns de grandes quantidades de rendas do comércio perderem-se das redes de trocas de mercadorias. Se por um lado estes investimentos res-

${ }^{62}$ Idem.

${ }^{63}$ Um desses «investidores» era Luiz Rodrigues Villares, comerciante que encabeçou o abaixo-assinado que analisamos no começo deste artigo. Antes de migrar para a Vila de Cuiabá, o então morador de São Paulo afirmava ter, desde 1720, ocupado terras nos campos de Curitiba e «povoado de escravos com princípio de 500 cabeças de gado vacuns e 50 de cavalar». Requerimento de sesmarias de Luiz Rodrigues Villares e Antonio Lopes Thomar, 12 de fevereiro de 1725. Requerimentos de sesmarias da Capitania de São Paulo, APESP, doc. 80-01-70.

${ }^{64}$ É o caso do já citado Luís Rodrigues Villares que tinha como sogro um importante homem de negócios da elite de São Paulo, Manuel Veloso, que, segundo Borrego (2006: 116) era um dos principais comerciantes da capitania.

${ }^{65}$ Livro de Sesmarias Patentes e Provisõe, APESP, Livro 2. 
pondem á aspirações nobiliárquicas bastante evidentes por outro permitem, justamente, a ultrapassagem de algumas «fronteiras» e a obtenção de privilégios para arrematação de contratos, obtenção de terras em locais estratégicos e além dos limites legalmente estabelecidos, vantagens no abastecimento de tropas de soldados, entre outros ${ }^{66}$.

Para os comerciantes de Cuiabá que, embora em condição periférica encontravam-se no interior das relações mercantis coloniais, a diversificação das atividades econômicas era um meio de salvaguardar parte dos lucros do comércio em atividades que garantiriam a continuidade da riqueza e a consolidação de um lugar social que permitisse, por exemplo, que uma reivindicação - mesmo que negada- chegasse ao rei e fosse avaliada por autoridades que integravam os mais altos cargos do sistema administrativo português.

No princípio deste artigo aceitamos o desafio de revelar aspectos gerais da reprodução da economia na América colonial, na primeira metade do século XVIII, partindo do estudo de aspectos específicos das atividades mercantis desenvolvidas nas minas do Cuiabá e do Mato Grosso. Esperamos que nosso trabalho signifique uma contribuição para a desafio de produzir conhecimento sobre a dinâmica das atividades econômicas coloniais nos interiores da América, em perspectivas que privilegiem o «jogo de escalas», pois, apesar das evidentes especificidades locais e regionais, essa dinâmica entrelaça uma densa trama de relações, interliga um sem-número de espacialidades e, em diversas escalas, retroalimenta o movimento do capital mercantil nas conquistas ibéricas na América.

${ }^{66} \mathrm{O}$ caráter aristocrático do investimento dos lucros do comércio por parte das elites coloniais é um aspecto discutido por vários autores e merece uma análise aprofundada que coloque em diálogo as diversas perspectivas. Contudo, como aqui não temos espaço para desenvolvê-la, deixemos dito que a perspectiva por nós esboçada aproxima-se das conclusões de Stuart Schwartz e de David Brading. Schwartz aponta que, do mesmo modo que em Portugal, França e Inglaterra, no Brasil colonial a «classe mercantil» investir em terras significava «a aquisição de uma relativa segurança e a limitação de seus riscos, ao mesmo tempo em que lhes fornecia status e imagem, uma série de vantagens que lhes deviam ser perceptíveis». Schwartz, 1999: 32. Brading afirma que para o comerciante do México colonial investir em terras era um modo de garantir a continuidade da sua fortuna, objetivo «paralelo a la ambición tan común de los mercadores ricos, de fundar una familia noble». Brading, 1975: 146. 


\section{BIBLIOGRAFIA}

Almeida, André Ferrand, “A viagem de José Gonçalves da Fonseca e a cartografia do rio Madeira (1749-1752)", Anais do Museu Paulista, XVII/2 (São Paulo, 2009): 215-235.

Alves, Maurício M., Caminhos da pobreza: a manutenção da diferença em Taubaté (1680-1729), Taubaté/SP, Prefeitura Municipal de Taubaté, 1998.

Ameghino, Eduardo Azcuy e Birocco, Carlos María, "As colônias do Rio da Prata e o Brasil: geopolítica, poder, economia e sociedade", Amado Luiz Cervo e Mario Rapoport (orgs.), História do Cone Sul, Brasília, Editora Universidade de Brasília, 1998: 11-76.

Arruda, José Jobson de A., O Brasil no comércio colonial, São Paulo, Editora Ática, 1980.

Assadourian, Carlos Sempat, El sistema de la economía colonial, Mercado interno, regiones y espacio económico, Lima, IEP, 1982.

Bastos, Uacury Ribeiro Assis, "Expansão territorial do Brasil Colônia no Vale do Paraguai (1767-1801)", Tese de Doutorado, São Paulo, USP, 1972.

Blaj, Ilana, A trama das tensões: o processo de mercantilização de São Paulo colonial (1681-1721), São Paulo, Humanitas/FAPESP, 2002.

Bethencourt, Francisco, "Political configurations and local powers", Francisco Bethencourt e Diogo Ramada Curto (orgs.), Portuguese Oceanic Expansion, 1400-1800, Nova York, Cambridge University Press, 2007: 197-254.

Braudel, Fernand, Civilização Material, Economia e Capitalismo século XV-XVIII, V. II, São Paulo, Martins Fontes, 2005.

Bonialian, Mariano, "México, epicentro semiinformal del comercio hispano-americano (1680-1740)", América Latina en la Historia Económica, XXXV (México D.F., 2011): 7-28.

Borrego, Maria A. M, “A Teia mercantil: negócios e poderes em São Paulo colonial (1711-1765)", Tese de Doutorado, São Paulo, USP, 2006.

Brading, David A, Mineros e comerciantes en el México borbónico (1763-1808), Tradução de Roberto Gomes de Ciriza, Madri, FCE, 1975.

Canabrava, Alice P., O comércio português no Rio da Prata (1580-1640), Belo Horizonte/São Paulo, Itatiaia/Edusp, 1984.

Canavarros, Otávio, O poder metropolitano em Cuiabá (1727-1752), Cuiabá, Edufmt, 2004.

Cardoso, Ciro F. S., Agricultura, escravidão e capitalismo, Petrópolis, Vozes, 1979.

Cardoso, Ciro F. S., Escravo ou camponês? O protocampesinato negro nas Américas, São Paulo, Brasiliense, 1987. 
Carrara, Angelo Alves, Minas e currais, Produção rural e mercado interno de Minas Gerais, 1674-1807, Juiz de Fora, Editora da UFJF, 2007.

Ceballos, Rodrigo, "Extralegalidade e Autotransformação no porto: a presença portuguesa na Bueno Aires Colonial (Século XVIII)", Territórios e Fronteiras, I/2 (Cuiabá, 2008): 300-317.

Chaves, Otávio Ribeiro, "Politica de Povoamento e a Constituição da Fronteira Oeste do Império Português: a Capitania de Mato Grosso na segunda metade do século XVIII", Tese de doutorado, Curitiba, UFPR, 2009.

Cortesão, Jaime, Alexandre de Gusmão e o Tratado de Madri, Rio de Janeiro, Instituto Rio Branco, 2001.

Davidson, David M., "How the brazilian west was won: freelance \& state on the Mato Grosso frontier, 1737-1752", Dauril Alden (org.), Colonial roots of modern Brazil, Berkeley, University of Califórnia, 1973: 61-106.

Donoso Anes, Rafael, "Un análisis sucinto del Asiento de esclavos con Inglaterra (1713-1750) y el papel desempeñado por la contabilidad en su desarrollo", Anuario de Estudios Americanos, LXIV/2 (Sevilla, 2007): 105-144.

Ferreira, Mario C., "Cartografar o sertão: a representação de Mato Grosso no século XVIII”, Anais II Simpósio Luso-Brasileiro de Cartografia Histórica, Lisboa, Instituto Geográfico Português, 2007: 1-20.

Florentino, Manolo e Fragoso, João, O arcaísmo como projeto: mercado atlântico, sociedade agrária e elite mercantil em uma economia colonial tardia: Rio de Janeiro, c. 1790- c. 1840, Rio de Janeiro, Sette Letras, 1998.

Flory, Rae Jean Dell e SMITH, David Grant, "Bahian merchants and the planters in the seventeenth and early eighteenth centuries", Hispanic American Historical Review, LVIII/4 (Durham, 1978): 571-594.

Fragoso, João, Homens de grossa aventura: acumulação e hierarquia na praça mercantil do Rio de Janeiro (1790-1830), Rio de Janeiro, Civilização Brasileira, 1998.

Garcia, João Carlos (coord.), A mais dilatada vista do mundo: inventário da coleção cartográfica da Casa da Ínsua, Portugal, CNCDP, 2000.

Ginzburg. Carlo, O queijo e os vermes. O cotidiano e as idéias de um moleiro perseguido pela Inquisição, Tradução Maria Betânia Amoroso, São Paulo, Cia. das Letras, 1989.

Ginzburg, Carlo, Mitos, emblemas, sinais: Morfologia e História, Tradução de Frederico Carotti, São Paulo, Cia das Letras, 1990.

Gomes, Masília Aparecida da Silva, “Os 'gêneros do país': a produção de alimentos em Vila Bela da Santíssima Trindade (1748-1790)", Leny Caselli Anzai e Maria Cristina Bohn Martins (orgs.), Histórias coloniais em áreas de fronteiras: índios, jesuitas e colonos, São Leopoldo/Cuiabá, Oikos/Unisinos/Edufmt, 2008: 99-125. 
Holanda, Sérgio Buarque de, Monções, São Paulo, Brasiliense, 1990.

Holanda, Sérgio Buarque de, Caminhos e fronteiras, São Paulo, Cia. das Letras, 1994.

Jesus, Nauk Maria, "Na trama dos conflitos: a administração na fronteira oeste da América portuguesa (1719-1778)", Tese de Doutorado, Niterói, UFF, 2006.

Levi, Giovanni. A herança imaterial: trajetória de um exorcista no Piemonte do século XVII. Tradução Cynthia Marques de Oliveira, Rio de Janeiro, Civilização Brasileira, 2000.

Lucidio, João Antonio Botelho, A Vila Bela e a ocupação portuguesa do Guaporé no século XVIII, Projeto Fronteira Ocidental Arqueologia e História -Vila Bela da Santíssima Trindade / MT. Relatório final, Fase 2, Cuiabá, Governo de Mato Grosso/Secretaria de Estado de Cultura/ Coordenadoria de Preservação do Patrimônio Cultural, Histórico, Artístico e Arqueológico Odir Burity, 2004.

Macleod, Murdo J., "Espanha e América: o comércio atlântico, 1492-1720”, Leslie Bethell (org.) História da América Latina, América Latina Colonial, v. 1, Tradução Maria Clara Cescato, São Paulo/Brasília, Edusp/Funag, 1997.

Mello, Evaldo Cabral de, A fronda dos mazombos, nobres contra mascates: Pernambuco 1666-1715, São Paulo, Cia das Letras, 1995.

Miller, Joseph C., "Capitalism and Slavery: the financial and commercial organization of the Angolan Slave Trade, according to the accounts of Antonio Coelho Guerreiro (1684-1692)". International Journal of African Historical Studies, 17/1 (Boston, 1984): 1-15.

Moutoukias, Zacarías, "Burocracia, contrabando y autotransformación de las elites: Buenos Aires en el siglo XVII", Anuario del IEHS, III (Buenos Aires, 1988): 213-248.

Novais, Fernando A., Portugal e Brasil na crise do Antigo Sistema Colonial (17771808), São Paulo, Hucitec, 1986.

Oliveira, Tiago Kramer de, "Entre dois impérios: conquistas portuguesas e ruralidade no centro da América do Sul (1716-1750)", Leny Caselli Anzai e Maria Cristina Bohn Martins (orgs.), Histórias coloniais em áreas de fronteiras: indios, jesuítas e colonos, São Leopoldo/Cuiabá, Oikos/Unisinos/Edufmt, 2008: 17-49.

Oliveira, Tiago Kramer de, "A paisagem do Pantanal e a ruralidade nas Minas do Cuiabá (primeira metade do século XVIII)", Revista de História, 164 (São Paulo, 2011): 161-194.

Parrón Salas, Carmen, "El nacionalismo emergente y el comercio, La expulsión de extranjeros de América (Perú), 1750-1778”, Actas del XI Congreso de la Asociación de Historiadores Latinoamericanistas Europeos, Liverpool, Universidad de Liverpool, 1996: 200-218. 
Parrón Salas, Carmen, "Perú y la transición del comercio político al comercio libre, 1740-1778", Annuario de Estudios Americanos, LIV/2 (Sevilla, 1997): 447-473.

Prado Júnior, Caio, Formação do Brasil Contemporâneo - colônia, São Paulo, Brasiliense, 1997.

Prado, Fabrício, Colônia de sacramento: o extremo sul da América portuguesa no século XVIII, Porto Alegre, F. P. Prado, 2002.

Prado, Fabricio, "Colônia de Sacramento: a situação na fronteira platina no século XVIII", Horizontes Antropológicos, 19 (Porto Alegre, 2003): 74-104.

Presotti, Thereza Martha, "Na Trilha das Águas: Índios e Natureza na conquista colonial do centro da América do Sul, sertões e minas do Cuiabá e mato Grosso, século XVIII (1718-1752)", Tese de Doutorado, Brasília, UNB, 2008.

Revel, Jacques (org.), Jogos de escalas: a experiência da microanálise, Tradução Dora Rocha, Rio de Janeiro, Fundação Getúlio Vargas, 1998.

Rodrigues, Nathalia M. D., "A capitania de Mato Grosso e a Companhia Geral de Comércio do Grão-Pará e Maranhão (1755-1778)”, Leny Caselli Anzai e Maria Cristina Bohn Martins (orgs.), Histórias coloniais em áreas de fronteiras: indios, jesuitas e colonos, São Leopoldo/Cuiabá, Oikos/Unisinos/Edufmt, 2008: 126-158.

Rosa, Carlos Alberto, "O urbano colonial na terra da conquista", Carlos Alberto Rosa e Maria de Jesus Nauk, A terra da conquista: história de Mato Grosso Colonial, Cuiabá, Adriana, 2003: 11-64.

Sampaio, Antonio Carlos Jucá de, Na encruzilhada do Império: hierarquias sociais e conjunturas econômicas no Rio de Janeiro (c. 1650-c.1750), Rio de Janeiro, Arquivo Nacional, 2001.

Schwartz, Stuart B., "Mentalidades e estruturas sociais no Brasil colonial: uma resenha coletiva", Economia e Sociedade, XIII (Campinas, 1999): 129-153.

Taunay, Affonso de E., História das Bandeiras Paulistas: relatos monçoeiros, Tomo III, Belo Horizonte/São Paulo, Itatiaia/Edusp, 1981.

Thompson, Edward P., Senhores e caçadores: a origem da lei negra, Tradução Denise Bottmann, Rio de Janeiro, Paz e Terra, 1987.

Volpato, Luiza Rios Ricci, A conquista da terra no universo da pobreza: formação da fronteira oeste do Brasil, São Paulo, HUCITEC, 1987.

Fecha de recepción: 7 de noviembre de 2013.

Fecha de envío de las modificaciones: 30 de enero de 2014.

Fecha de aceptación: 13 de febrero de 2014. 


\section{El capital mercantil en el centro de América del Sur y las fronteras del comercio en la América colonial (primera mitad del siglo XVIII)}

Este artículo examina la reproducción de la economía colonial en el centro de América del Sur, en la Vila Real do Senhor Bom Jesus de Cuiabá. A través de las distintas fuentes consultadas investigamos cómo la dinámica de la economía local se relacionó con cambios en contextos más amplios, en la primera mitad del siglo XVIII. Nuestro objetivo es dar a conocer cómo las dinámicas locales estaban relacionadas con las "fronteras del comercio" y la consiguiente expansión de explotación comercial en los interiores de Iberoamérica Colonial.

Palabras clave: Brasil; América del Sur; comercio colonial; economía colonial; siglo XVIII; fronteras.

\section{The Mercantile Capital in the Center of South America and the Borders of Trade in Colonial America (First Half of the Eighteenth Century)}

This article analyzes the reproduction of the colonial economy at Vila Real do Senhor Bom Jesus do Cuiabá, in the center of South America. Using various types of documents, we investigated how the dynamics of the local economy were connected with changes occurring within a broader context, in the first half of the eighteenth century. Our objective is to highlight how the local dynamics were related to the "trade borders" and the consequent expansion of commercial exploitation in the hinterlands of Ibero-America.

Key words: Brazil; South America; Colonial Trade; Colonial Economy; Eighteenth Century; Borders. 